\title{
HAMBATAN KOMUNIKASI ANTAR BUDAYA DALAM PENERJEMAHAN DI PERUSAHAAN MODAL ASING JEPANG
}

\author{
Ulfi Zakiyah Luthfiyah \\ (ulfizakiyahlithfiyah@yahoo.co.id) \\ (Alumni S1 Program Studi Imu Komunikasi Universitas Semarang)
}

\begin{abstract}
:
This study aims to find out the barriers of intercultural communication that occurs in the Japanese translation - Indonesian and vice versa in PT. METEC Semarang, which is the capital of Japan's foreign companies. The theory used in this study are speech codes theory, where acts of communication is not only seen from the spoken words alone, but cultural background, facial expressions, gestures, intonation is a unity that would give meaning to the act of communication. The results of this study indicate that there are two obstacles, namely the translation of external factors and internal factors. External factors consist of technical terms and new terms, length of utterance, speaking speed, and tone of voice. Internal factors consist of cognitive factors, namely speed and vocabulary to understand the message, and psychological factors are anxiety is high.
\end{abstract}

Kata Kunci : Penerjemahan, Speech codes theory, Hambatan komunikasi

\section{Pendahuluan}

Era globalisasi ini pertukaran kebudayaan menjadi hal yang tidak bisa dihindari. Kebudayaan-kebudayaan asing masuk dengan mudah ke Indonesia melalui berbagai macam teknologi informasi dan komunikasi. Tidak hanya itu, orang asing yang tinggal di Indonesia juga ikut berperan dalam menyebarkan kebudayaan negara asalnya. Mudahnya interaksi dan komunikasi dengan negara lain membuat apa yang disebut dengan komunikasi antar budaya menjadi hal yang tidak terhindarkan lagi. "Komunikasi antar budaya terjadi bila produsen pesan adalah anggota suatu budaya dan penerima pesannya adalah anggota suatu budaya lainnya" (Deddy dan Rakhmat, 2010: 30).

Jika orang Indonesia berbicara dengan orang yang berasal dari negara lain, maka dapat dikatakan bahwa komunikasi yang terjadi antara mereka adalah komunikasi antar budaya.
Komunikasi antar budaya ini hanya dapat berjalan lancar apabila kedua belah pihak dapat menggunakan bahasa yang dapat dimengerti oleh keduanya. Orang asing yang tinggal di Indonesia memiliki pengaruh yang besar dalam menciptakan peluang terjadinya komunikasi antar budaya dan menyebarkan kebudayaan negaranya.

Hal ini disebabkan karena mereka hampir setiap hari melakukan interaksi dengan masyarakat sekitar. Seperti halnya yang terjadi di PT. METEC Semarang, tujuh orang ekspatriat Jepang tidak sungkansungkan menerapkan pola atau sistem kerja Jepang di perusahaan yang notabene semua karyawannya adalah orang Indonesia. Bahkan istilah-istilah asing juga diterapkan dalam bekerja seperti seisansei, gentan-I, dan kaizen. Setiap harinya terjadi komunikasi antar budaya antara ekspatriat Jepang dan staf Indonesia. Bagi staf Indonesia yang bisa berbahasa Jepang, komunikasi dapat 
berjalan dengan lancar. Namun untuk staf Indonesia yang tidak bisa berbahasa Jepang akan kesulitan untuk membangun sebuah komunikasi yang efektif. Ekspatriat Jepang di PT.METEC Semarang menginginkan stafnya untuk bekerja menggunakan pola PDCA atau Plan, Do, Check, dan Action. Namun, karena komunikasi yang tidak bisa berjalan dengan efektif, staf Indonesia tidak dapat merespon sesuai dengan keinginan ekspatriat. Demi menciptakan iklim komunikasi yang kondusif, PT. METEC Semarang menggunakan Penerjemah sebagai jembatan komunikasi antara ekspatriat Jepang dan staf Indonesia.

Penerjemah berperan sebagai media komunikasi yang bertugas untuk menerjemahkan lambang dalam Bahasa Jepang kepada staf Indonesia. Menilik unsur-unsur komunikasi yang terdiri dari sumber, penyandian, pesan, channel, dan penerima, maka penerjemah dapat diibaratkan sebagai channel yang menjadi penghubung antara ekspatriat Jepang dan staf Indonesia. Penerjemah bertugas untuk menyampaikan pesan secara utuh dan tepat dari komunikator ke komunikan. Meskipun Penerjemah telah belajar Bahasa Jepang sebelumnya, namun terkadang Penerjemah masih menemui kesulitan-kesulitansaat menerjemahkan. Akan lebih mudah lagi bagi Penerjemah, jika dia telah memiliki gambaran mengenai apa yang dibicarakan oleh komunikator.

Memiliki gambaran tentang apa yang diterjemahkan, mempermudah Penerjemah untuk memahami sebuah pesan secara tepat dan menyampaikannya dengan tepat pula. Namun ada pula saatnya Penerjemah sama sekali tidak bisa mengira-ngira arti dari sebuah kosa kata. Pada saat itu penerjemah harus meminta penjelasan terkait arti kata tersebut kepada komunikator supaya tidak salah menerjemahkan. Seorang penerjemah tidak diperbolehkan untuk menerjemahkan sesuatu yang dia sendiri belum memahaminya, karena kesalahan penerjemahan berarti merubah isi dari pesan komunikator yang menyebabkan komunikan akan memberikan respon dan feedback yang mungkin tidak diharapkan oleh komunikator.

Keterbatasan kosakata tidak adanya gambaran bukanlah satu-satunya masalah dalam hal menerjemahkan dan membangun sebuah komunikasi antar budaya yang efektif. Masih banyak halhal lain yang menjadi noise atau gangguan saat melakukan komunikasi antar budaya dalam konteks penerjemahan. Penulis melakukan penelitian di PT. METEC Semarang untuk mengetahui hamabatn-habatan dalam penerjemahan Bahasa Jepang Bahasa Indonesia.

Sebagaimana yang telah didefinisikan oleh Philipsen, kode-kode berbicara ditransmisikan secara historis, merupakan sistem simbol dan makna yang dibangun secara sosial, dasar pemikiran dan aturan-aturan yang merujuk pada perilaku komunikatif. Kode, dengan kata lain, adalah sistem atau pola bahasa yang kaya akan makna sosikultural bagi penggunanya (Little John\&Foss, 2009: 921). Speech Codes Theory terdiri dari enam proposisi yaitu (1) Di mana ada suatu perbedaan budaya, disanalah akan ditemukan kode berbicara yang berbeda pula, (2) Dalam komunitas berbicara, kode-kode berbicara yang majemuk disebarkan, (3) Kode berbicara melibatkan perbedaan kultural dalam segi psikologi, sosiologi, dan retorik), (4) Pentingnya pembicaraan bergantung pada kodekode berbicara yang digunakan oleh lawan bicara (komunikator) untuk membentuk tindakan komunikatif, (5) Istilah, aturan, dan premis dari kode berbicara 
terjalin atau menyatu ke dalam pembicaraan itu sendiri, dan (6) Seni menggunakan kode-kode berbicara bersama adalah sebuah kondisi yang memadai untuk memprediksikan, menjelaskan, dan mengendalikan bentuk wacana tentang kejelasan, kebijaksanaan, dan moralitas dari tindakan komunikasi.

\section{Pembahasan}

PT. METEC Semarang merupakan salah satu anak perusahaan Kubota Jepang yang bergerak dalam bidang manufacturing vending machine. PT. METEC Semarang berdiri pada tahun 1996 dan berlokasi di Jalan Coaster No. 8 Blok B 12 A- 16 semarang. Di PT. METEC Semarang terdapat tujuh orang ekspatriat Jepang yang menduduki jabatan-jabatan strategis sebagai Presiden Direktur, Direktur, Koordinator, dan Manajer.

Komunikasi antar budaya terjadi setiap harinya di PT. METEC Semarang antara staf Jepang dan staf Indonesia baik yang bisa berbahasa Jepang maupun yang tidak. Bagi staf yang tidak bisa berbahasa Jepang komunikasi akan dijembatani oleh Penerjemah yang keberadaannya dianggap sangat penting di perusahaan demi memperlancar komunikasi dan penyampaian informasi. Penerjemah di PT. METEC Semarang menggunakan cara penerjemahan konsekutif.

Penerjemahan ini dianggap paling efektif mengingat adanya perbedaan susunan pola kalimat dalam Bahasa Indonesia dan Bahasa Jepang. Pola kalimat Bahasa Indonesia adalah SPOK (Subjek, Predikat, Objek, Keterangan), sementara pola kalimat Bahasa Jepang adalah KSOP (Keterangan, Subjek, Objek, dan Predikat). Penulis menemukan faktafakta di lapangan sesuai dengan teori yang penulis gunakan yaitu Speech Codes Theory. Setelah menganalisis data-data yang Penulis kumpulkan, Penulis melihat bahwa berbicara, simbol, dan kode-kode yang diberikan seseorang merupakan sebuah tindakan komunikasi dan tindakan komunikasi tidak hanya dilihat dari perkataan sajatetapi cara berbicara, kosa kata yang digunakan, intonasi, gesture, mimik wajah ikut membangun makna tindakan komunikasi itu sendiri. Faktafakta di lapangan sesuai dengan keenam proposisi dalam Speech Codes Theory, bahwa selalu terdapat perbedaan kodekode berbicara dalam budaya yang berbeda yang tentunya menjadi hambatan tersendiri bagi Penerjemah, meskipun hambatan tersebut tidak besar dikarenakan Penerjemah sudah memiliki bekal pengetahuan Bahasa Jepang di bangku kuliah. Perbedaanperbedaan huruf dan pola kalimat dapat diatasi dengan baik oleh Penerjemah. Namun, kosa kata atau istilah khusus baru dan yang belum pernah didengar oleh penerjemah sebelumnya akan menjadi sebuah hambatan dalam penerjemahan.

Contohnya saat terdapat kata yang image-nya ada dalam Bahasa Indonesia ataupun Bahasa Jawa belum tentu dapat diterjemahkan secara sempurna atau secara tepat dalam Bahasa Jepang dikarenakan terbatasnya kosa kata dalam Bahasa Indonesia maupun Bahasa Jepang. Kata "Mbledrek" sebenarnya kurang tepat jika diterjemahkan dengan kata Tokeru yang berarti meleleh, karena kata meleleh artinya mencairkan. Sementara yang dimaksud dengan "Mbledrek" adalah sebagian rou pengelasan memadat, sebagian yang lain turun kebawah dan memadat di sana. Namun, hambatan ini bisa diminimalisir, apabila komunikator, komunikan dan Penerjemah melihat aktual barang atau melihat kondisi yang dimaksud secara langsung. Dalam menerjemahkan 
Penerjemah juga selalu melihat siapa yang berbicara dan siapa yang mendengarkan. Penerjemah sudah mengetahui dan memahami karateristik dari staf-staf Jepang yang bekerja di PT. Metec Semarang. Memahami karateristik staf Jepang membuat Penerjemah mudah untuk mengetahui apa yang diinginkan oleh staf Jepang, dan mudah untuk menduga kemana arah pembicaraan yang sedang berlangsung. Sehingga, Penerjemah dapat menciptakan sebuah terjemahan yang utuh, tidak hanya sekedar makna kata namun juga langsung menyasar pada maksud pesan dari komunikator. Contoh mudahnya adalah sebagai berikut: Tadayuki Masuda: いつ報告しますか？（itsuhoukokushi masuka?/kapan kamu akan memberikan laporan?) Penerjemah: Tanggal berapa akan dilaporkan?

Dalam kasus tersebut di atas, Penerjemah tidak menerjemahkan dengan kapan kamu akan memberikan laporan, dikarenakan Penerjemah sudah memahami dengan baik karakter dari staf Jepang maupun staf Indonesianya. Staf Jepang selalu menginginkan jawaban yang spesifik, jika bertanya kapan maka jawaban yang harus muncul adalah tanggal, hari, dan waktu. Namun, jika orang Indonesia ditanya kapan, maka biasanya dan sebagian besar akan menjawab besok, lusa, atau satu minggu lagi. Supaya perbedaan interpretasi ini tidak muncul dan komunikasi dapat berjalan lancar, maka Penerjemah menerjemahkannya dengan kata "tanggal berapa". Dengan begitu, jawaban yang dikeluarkan oleh orang Indonesia adalah jawaban spesifik dan sesuai dengan harapan staf Jepang. Sesuai dengan Proposisi kedua sampai keenam dalam Speech Codes Theory, perbedaan latar belakang budaya, sosial, dan karakteristik akan mempengaruhi cara seseorang berkomunikasi.
Menyadari akan hal itu, Penerjemah di PT. METEC Semarang selalu melihat siapa yang berbicara dan siapa yang mendengarkan untuk memutuskan katakata yang akan digunakan supaya pesan yang disampaikan oleh komunikator dapat diterima baik oleh komunikan.

Hal yang sulit bagi Penerjemah adalah apabila komunikator mengeluarkan ekspresi-ekspresi non verbal tertentu yang sulit untuk ditirukan oleh Penerjemah sendiri. Ekspresi-ekspresi komunikator saat marah, gesture komunikator saat jengkel, nada bicara komunikator yang tinggi penuh emosi menjadi hambatan yang cukup sulit bagi Penerjemah. Pasalnya Penerjemah memiliki rasa sungkan terhadap komunikan, sehingga

Penerjemah tidak menirukan ekspresi komunikator melainkan hanya menerjemahkan perkataan komunikator. Meskipun begitu, Penerjemah berusaha untuk menyesuaikan intonasi suara dan ucapannya sesuai dengan emosi yang ditunjukkan oleh komunikator.

Di lapangan Penulis juga menemukan faktor-faktor baru yang menjadi hambatan bagi Penerjemahan di PT. METEC Semarang. Faktor tersebut Penulis bagi menjadi dua yaitu faktor eksternal dan faktor internal. Faktor eksternal yaitu penggunaan technical term dan istilah baru, panjang ucapan, kecepatan berbicara dan intonasi sumber suara. Sementara itu untuk faktor internal adalah faktor kognitif dan faktor psikis Penerjemah itu sendiri. Faktor kognitif meliputi kecepatan memahami pesan yang disampaikan oleh komunikator dan perbendaharaan kata. Sementara faktor psikis adalah kegelisahan yang tinggi dalam diri Penerjemah yang disebabkan oleh mereka merasa belum memahami materi yang disampaikan, takut salah, kurangnya rasa percaya diri sehingga mengurangi konsentrasi dan fokus saat 
menerjemahkan. Penerjemah seringkali merasa kurang percaya diri saat harus menerjemahkan di depan orang yang bisa dan mengerti berbahasa Jepang.

Kehadiran orang tersebut akan memunculkan tekanan akan rasa takut berbuat kesalahan dalam diri Penerjemah. Ujung-ujungnya Penerjemah tida bisa fokus dengan baik pada apa yang dikatakan oleh komunikator, sehingga penyampaian pesan pun tidak bisa berjalan dengan baik. Untuk menanggulangi kegelisahan yang tinggi ini, Penerjemah dapat meningkatkan kemampuan kognitifnya dengan cara banyak membaca teks-teks panjang yang berhubungan dengan pekerjaan dan menghafal kata-kata baru untuk memperkaya kosa kata dengan membaca berita di NHK. Apabila kemampuan kognitif Penerjemah meningkat, maka Penerjemah akan memiliki rasa percaya diri yang lebih baik dan kegelisahan yang tinggi dapat dikurangi atau bahkan dihilangkan.

\section{Kesimpulan}

Hasil penelitian di lapangan sesuai dengan teori yang Penulis gunakan yaitu Speech Codes Theory. Dari enam proposisi dalam Speech Codes Theory dapat disimpulkan bahwa perbedaan budaya, latar belakang budaya, sosial, gesture akan memunculkan kode-kode berbicara yang berbeda dan majemuk. Di mana perbedaan kode-kode berbicara ini akan menjadi hambatan dalam Penerjemah. Di PT. METEC Semarang perbedaan bahasa, tulisan, dan pola kalimat tidak menjadi hambatan yang besar, namun istilahistilah baru atau kata-kata khusus yang belum pernah didengar sebelumnya akan menjadi hambatan dalam komunikasi yang dijembatani oleh Penerjemah.

Hambatan dalam penerjemahan di PT. METEC Semarang terdiri dari dua faktor yaitu faktor eksternal dan factor internal. Faktor eksternal yaitu penggunaan technical term dan istilah baru, panjang ucapan, kecepatan berbicara, dan intonasi sumber suara. Sementara itu untuk faktor internal adalah faktor kognitif dan faktor psikis Penerjemah itu sendiri. Faktor kognitif meliputi kecepatan memahami pesan yang disampaikan oleh komunikator dan perbendaharaan kata. Sementara faktor psikis adalah kegelisahan yang tinggi dalam diri Penerjemah yang disebabkan oleh merasa belum memahami materi yang disampaikan, takut salah, kurangnya rasa percaya diri sehingga mengurangi konsentrasi dan fokus saat menerjemahkan. Kegelisahan yang tinggi dapat diatasi oleh Penerjemah dengan cara meningkatkan kemampuan kognitifnya untuk memahami kalimat dengan cepat dan menambah perbendaharaan katanya.

Penerjemah dapat membaca teks-teks panjang maupun membaca berita-berita yang ditulis oleh NHK untuk memaham pola kalimat Bahasa Jepang secara baik dan benar dan menambah perbendaharaan kosa katanya. Seiring dengan meningkatkan kemampuan kognitif Penerjemah, maka kegelisahan yang tinggi dapat diminimalisir atau bahkan dihilangkan.

\section{Daftar Pustaka}

Deddy Mulyana dan Jalaluddin Rakhmat. (2010). Komunikasi Antar Budaya. Bandung: PT Remaja Rosdakarya.

LittleJohn, Stephen W dan Foss, Karen A. (2009). Encyclopedia of Communication Theory. USA: SAGE publication Inc. 